\title{
Marinobacter szutsaonensis sp. nov., isolated from a solar saltern
}

\author{
Chung-Yi Wang, Chang-Chai Ng, Wen-Sheng Tzeng and Yuan-Tay Shyu
}

Correspondence

Yuan-Tay Shyu

tedshyu@ntu.edu.tw
Department of Horticulture, National Taiwan University, 140, Keelung Road, Section 4, Taipei 106, Taiwan, ROC

\begin{abstract}
A Gram-negative, aerobic, non-spore-forming, halophilic bacterial strain, NTU-104 ${ }^{\top}$, was isolated from the Szutsao saltern in southern Taiwan, which was previously used as salt production field. The novel isolate grew optimally at $35-40{ }^{\circ} \mathrm{C}$, at $\mathrm{pH} 7.5-8.0$ and in the presence of $5 \%(\mathrm{w} / \mathrm{v})$ $\mathrm{NaCl}$. The major fatty acids were $\mathrm{C}_{16: 0}, \mathrm{C}_{18: 1} \omega 9 c, \mathrm{C}_{16: 1} \omega 9 c, \mathrm{C}_{12: 0} 3-\mathrm{OH}$ and $\mathrm{C}_{12: 0}$. The predominant quinone was Q-9. Phosphatidylglycerol, diphosphatidylglycerol and phosphatidylethanolamine were the predominant polar lipids. The DNA G $+\mathrm{C}$ content was $56.5 \mathrm{~mol} \%$. Phylogenetic analyses based on 16S rRNA gene sequences revealed the affiliation of the novel isolate to the genus Marinobacter. DNA-DNA hybridization results between strain $\mathrm{NTU}-104^{\top}$ and the type strains of the most closely related species, Marinobacter pelagius and Marinobacter koreensis, were $36.4 \%$ and $33.2 \%$, respectively. On the basis of phenotypic, phylogenetic and genetic analyses, strain NTU-104 ${ }^{\top}$ is considered to represent a novel species of the genus Marinobacter. The name Marinobacter szutsaonensis sp. nov. is proposed, with strain NTU-104 ${ }^{\top}\left(=\right.$ BCRC $17809^{\top}=$ CGMCC $\left.1.7011^{\top}=J C M 15751^{\top}\right)$ as the type strain.
\end{abstract}

The genus Marinobacter, a member of the class Gammaproteobacteria, was first proposed by Gauthier et al. (1992). The type species of the genus, Marinobacter hydrocarbonoclasticus, was isolated from sediments collected in the Gulf of Fos (French Mediterranean coast) at the mouth of a petroleum refinery outlet chronically polluted by hydrocarbons (Gauthier et al., 1992). Recently, many further species, for example Marinobacter gudaonensis (Gu et al., 2007), Marinobacter salsuginis (Antunes et al., 2007), Marinobacter segnicrescens (Guo et al., 2007), Marinobacter salicampi (Yoon et al., 2007), Marinobacter pelagius (Xu et al., 2008), Marinobacter guineae (Montes et al., 2008), Marinobacter psychrophilus (Zhang et al., 2008), Marinobacter mobilis and Marinobacter zhejiangensis (Huo et al., 2008) have been described and, at the time of writing, the genus includes 23 recognized species. Species of this genus are Gram-negative, aerobic, motile, rodshaped bacteria. All previously described members of this genus have been found to contain $\mathrm{C}_{16: 0} \omega 9 c, \mathrm{C}_{16: 1} \omega 9 c$ and $\mathrm{C}_{18: 1}$ as the predominant fatty acids and to have DNA $\mathrm{G}+\mathrm{C}$ contents ranging from 53 to $59.6 \mathrm{~mol} \%$ (Liebgott et al., 2006). In this study, a morphological, biochemical,

Abbreviations: EPS, exopolysaccharides; PHA, poly- $\beta$-hydroxyalkanoate. The GenBank/EMBL/DDBJ accession number for the 16S rRNA gene sequence of strain NTU-104 ${ }^{\top}$ is EU164778.

A table detailing the fatty acid contents of strain NTU-104 ${ }^{\top}$ and some related species of the genus Marinobacter and figures showing the polar lipid analysis and additional phylogenetic trees are available with the online version of this paper. chemotaxonomic, genetic and phylogenetic characterization of a halophilic Marinobacter-like strain, NTU-104 ${ }^{\mathrm{T}}$, was conducted.

A single isolate of strain NTU- $104^{\mathrm{T}}$ was obtained from soil sediment that was collected from Szutsao saltern, southern Taiwan. The isolate was cultured by the dilution method (Wang et al., 2008). Briefly, soil sediment was dissolved in distilled water, diluted 1:1 with solutions of 5, 10, 15 and $20 \%(\mathrm{w} / \mathrm{v}) \mathrm{NaCl}$ and plated on basal medium agar plates. The $\mathrm{pH}$ of the agar plate was adjusted to 7.0 by the addition of $1 \mathrm{M} \mathrm{NaOH}$. The plates were then incubated at $37{ }^{\circ} \mathrm{C}$ for five days. Single colonies with various morphologies were selected for the growth condition tests. The salt requirements of these isolates were determined using basal medium $\left[1^{-1}: 5\right.$ g yeast extract (Difco), $5 \mathrm{~g}$ Casamino acid (Difco), $5 \mathrm{~g} \mathrm{MgSO}_{4} \cdot 7 \mathrm{H}_{2} \mathrm{O}$ ] with $0-30 \%$ (w/v) $\mathrm{NaCl}$ content. The optimal conditions for growth were determined on basal medium with various temperatures (10$70{ }^{\circ} \mathrm{C}$ ) and $\mathrm{pH}$ values $(4-10)$. The growth rate was monitored using a spectrophotometer at $\mathrm{OD}_{660}$. The Gram-reaction was monitored by Gram staining using Gram Stain kits (BD), according to the manufacturer's instructions. The ability of the novel strain to utilize various carbohydrates and amino acids was tested by using the GN2 MicroPlate Identification Test Panel (Biolog). The results were read with a MicroPlate reader, using MicroLog 3.59 software to perform automated reading and identification. Tests for the hydrolysis of aesculin, gelatin, starch, Tween 20 and Tween 80, for oxidase and catalase reactions and for $\mathrm{H}_{2} \mathrm{~S}$ production were performed as 
described by Mata et al. (2002). Enzyme activity was determined using the API ZYM system (bioMérieux). Sensitivity to antimicrobial agents was determined in basal medium that contained $50 \mathrm{mg} \mathrm{l}^{-1}$ of each antimicrobial agent for at least three days. The antimicrobial agents used were ampicillin, bacitracin, carbenicillin, cefotaxime, chloramphenicol, erythromycin, kanamycin, nalidixic acid, neomycin, nitrofurantoin, novobiocin, nystatin, penicillin, polymyxin B, rifampicin, streptomycin and tetracycline. Cell morphology was observed by scanning electron microscopy. The sample was fixed and processed following the recommended procedure for preparing specimens (Antón et al., 2002). Gold was used to coat the samples to an approximate thickness of $5 \mathrm{~nm}$. The samples were subsequently observed under a scanning electron microscope (Topcon Co.). Exopolysaccharides (EPS) were observed by the method of Azeredo \& Oliveira (1996). Poly- $\beta$-hydroxyalkanoate (PHA) detection was performed using GC as described by Mas-Castellà \& Guerrero (1995).

The $\mathrm{G}+\mathrm{C}$ content of DNA was determined using the method of Mesbah et al. (1989). The nucleotide mixtures were separated by HPLC (JASCO) using a Phenomenex $\mathrm{C} 18$ column. The set conditions were a flow rate of $1.0 \mathrm{ml}$ $\min ^{-1}$ at a temperature of $37^{\circ} \mathrm{C}$, quantified by measurement of $\mathrm{OD}_{260}$. Non-methylated bacteriophage $\lambda$ DNA (Sigma) was used as the calibration reference. The composition of the fatty acid methyl esters (FAME) was analysed using the standard procedure of the Microbial Identification software (MIDI). The extraction of the fatty acids was performed as described by Heyrman et al. (1999). Grown cultures were transferred on to trypticase soy agar (TSA) plates, which contained 3\% (w/v) trypticase soy broth, $1.5 \%(\mathrm{w} / \mathrm{v})$ Bacto-Agar (Difco) and $7 \%(\mathrm{w} / \mathrm{v}) \mathrm{NaCl}$ for $24 \mathrm{~h}$ at $37{ }^{\circ} \mathrm{C}$. Single colonies were removed using a platinum inoculating loop and transferred to $10 \mathrm{ml}$ Teflon centrifuge tubes with Teflon screw caps (Nalge Nunc International). FAME profiles were obtained by GLC using a model 6890N GC (HP) as described by Descheemaeker \& Swings (1995). The identity of the quinones was determined by HPLC (Shin et al., 1996). Polar lipids were analysed by two-dimensional TLC, as described by Komagata \& Suzuki (1987).

The nucleic acids of the novel isolates were extracted using a FastDNA Spin kit (Bio 101), following the manufacturer's instructions. Two universal primers (9F and 1492R) were used to amplify the 16S rRNA gene (Stackebrandt \& Liesack, 1993). The amplification was performed using a GeneAmp PCR system 9700 (Applied Biosystems). Amplicons were later sequenced (Mission Biotech) and aligned with representatives from the genus Marinobacter and related taxa using multiple sequence alignment software (CLUSTAL W 1.82; Thompson et al., 1994). A phylogenetic tree was constructed with the neighbourjoining, maximum-likelihood and maximum-parsimony algorithms with a bootstrap robustness of 1000 using PHYLIP package 3.6b. DNA-DNA hybridization was per- formed fluorometrically in triplicate using the method of Ezaki et al. (1989).

Strain NTU- $104^{\mathrm{T}}$ was found to be a Gram-negative, motile rod that grew optimally in medium that contained approximately $5 \%(\mathrm{w} / \mathrm{v})$ salt. This bacterium exhibited extreme halotolerance since it was able to grow in a medium containing $0-20 \%(\mathrm{w} / \mathrm{v}) \mathrm{NaCl}$. M. hydrocarbonoclasticus is also an extremely halotolerant species, whereas $M$. pelagius is a moderately halophilic bacterium with optimal growth at $5 \% \mathrm{NaCl}$. Strain NTU- $104^{\mathrm{T}}$ grew at $10-50{ }^{\circ} \mathrm{C}$ and at $\mathrm{pH} 6-$ 8.5; optimal growth occurred at $35-40{ }^{\circ} \mathrm{C}$ and at $\mathrm{pH} 7.5-$ 8.0. The new isolate was aerobic and catalase- and oxidasepositive. EPS and PHA were not produced. Detailed results are given in the species description.

The major components of the fatty acids detected in strain NTU-104 ${ }^{\mathrm{T}}$ were $\mathrm{C}_{16: 0} \quad(37.8 \%), \quad \mathrm{C}_{18: 1} \omega 9 c \quad(23.7 \%)$,

Table 1. Differential phenotypic characteristics of strain NTU $-104^{\top}$ and other species of the genus Marinobacter

Species: 1, NTU-104 ${ }^{\mathrm{T}}$ (data from the present study); 2, M. pelagius $\mathrm{HS}_{22} 5^{\mathrm{T}}$ (data from the present study and $\mathrm{Xu}$ et al., 2008); 3, M. koreensis $\mathrm{DD}-\mathrm{M} 3^{\mathrm{T}}$ (data from the present study and Kim et al., 2006); 4, M. gudaonensis SL014B61 $\mathrm{A}^{\mathrm{T}}$ (data from the present study and $\mathrm{Gu}$ et al., 2007). All strains are positive in tests for motility, catalase- and oxidase-activities and for the utilization of acetate and pyruvate. All strains exhibit cream coloured colonies. All strains are negative for the hydrolysis of gelatin and urea.

\begin{tabular}{|c|c|c|c|c|}
\hline Characteristic & 1 & 2 & 3 & 4 \\
\hline \multicolumn{5}{|l|}{ Range for growth } \\
\hline $\mathrm{NaCl}(\%, \mathrm{w} / \mathrm{v})$ & $0-20$ & $0.5-15$ & $0.5-20$ & $0-15$ \\
\hline $\mathrm{pH}$ & $6-8.5$ & $6-9$ & $5-9$ & $6-9.5$ \\
\hline Temperature range $\left({ }^{\circ} \mathrm{C}\right)$ & $10-50$ & $4-50$ & $10-45$ & $10-45$ \\
\hline Nitrate reduction & + & + & + & + \\
\hline Amylase & - & - & - & + \\
\hline Hydrolysis of Tween 80 & - & + & + & + \\
\hline \multicolumn{5}{|l|}{ Utilization of: } \\
\hline Acetate & + & + & + & + \\
\hline L-Alanine & + & + & - & + \\
\hline L-Arabinose & + & - & - & - \\
\hline Cellobiose & - & - & - & - \\
\hline Citrate & - & - & - & + \\
\hline D-Fructose & - & - & - & + \\
\hline Gluconate & - & - & - & - \\
\hline D-Glucose & + & - & - & + \\
\hline Glutamate & - & + & + & + \\
\hline Glycerol & - & - & - & + \\
\hline Maltose & + & - & - & + \\
\hline D-Mannitol & + & - & - & - \\
\hline Succinate & - & + & - & + \\
\hline Sucrose & + & - & - & - \\
\hline $\begin{array}{l}\text { DNA G }+ \text { C content } \\
(\mathrm{mol} \%)^{*}\end{array}$ & 56.5 & $59.0^{a}$ & $54.1^{b}$ & $57.9^{c}$ \\
\hline
\end{tabular}

${ }^{\star}$ Data from: $a, \mathrm{Xu}$ et al. (2008); b, Kim et al. (2006); c, Gu et al. (2007). 
$\mathrm{C}_{16: 1} \omega 9 c(10.2 \%), \mathrm{C}_{12: 0} 3-\mathrm{OH}(9.3 \%)$ and $\mathrm{C}_{12: 0}(7.8 \%)$. The fatty acid profile was similar to those of other species of the genus Marinobacter, in particular to that of $M$. pelagius (Gu et al., 2007; Guo et al., 2007; Xu et al., 2008) (see Supplementary Table S1, available in IJSEM Online). The major isoprenoid quinone of strain NTU-104 ${ }^{\mathrm{T}}$ was Q9. Phosphatidylglycerol, diphosphatidylglycerol and phosphatidylethanolamine were the major polar lipids (see Supplementary Fig. S2 in IJSEM Online). The DNA $\mathrm{G}+\mathrm{C}$ content of strain NTU-104 ${ }^{\mathrm{T}}$ was $56.5 \mathrm{~mol} \%$, which was within the range found previously for recognized species of the genus Marinobacter (Table 1).

The 16S rRNA gene sequence of strain NTU-104 ${ }^{\mathrm{T}}$ as determined in this study comprised 1435 nt. Comparative $16 \mathrm{~S}$ rRNA gene sequence analyses showed that strain NTU$104^{\mathrm{T}}$ was most closely related to species of the genus Marinobacter (Fig. 1). Phylogenetic analysis based on $16 \mathrm{~S}$ rRNA gene sequence comparisons showed that strain NTU- $104^{\mathrm{T}}$ formed a coherent cluster with $M$. pelagius with high bootstrap resampling value ( $98.7 \%$ by the neighbourjoining method). Other phylogenetic trees were con- structed by means of the maximum-likelihood and maximum-parsimony algorithms. Although the tree topologies were slightly different, the relationships between the species of the genus Marinobacter were similar (see Supplementary Figs S3 and S4 in IJSEM Online). Strain NTU-104 ${ }^{\mathrm{T}}$ exhibited high $16 \mathrm{~S}$ rRNA gene sequence similarity to M. pelagius JCM $14804^{\mathrm{T}}(98.7 \%)$, M. koreensis $\mathrm{DD}^{\mathrm{M}} 3^{\mathrm{T}}(97.2 \%)$ and $M$. gudaonensis SL014B61A ${ }^{\mathrm{T}}$ (97.0\%). The DNA-DNA relatedness of strain NTU-104 ${ }^{\mathrm{T}}$ to $M$. pelagius $\mathrm{HS}_{225^{\mathrm{T}}}, M$. koreensis $\mathrm{DD}-\mathrm{M} 3^{\mathrm{T}}$ and $M$. gudaonensis SL014B61A $\mathrm{A}^{\mathrm{T}}$ was $36.4 \%(\mathrm{SD}=3.8 \%), 33.2 \%$ $(\mathrm{SD}=4.1 \%)$ and $30.7 \%(\mathrm{SD}=4.6 \%)$, respectively. All of these values were clearly below the $70 \%$ threshold that is generally used to delineate species. Thus, the 16S rRNA gene sequence data comparisons and DNA-DNA hybridization results demonstrated that strain NTU- $104^{\mathrm{T}}$ was most closely related to the genus Marinobacter but that the novel strain was not a member of any recognized species of this genus. In conclusion, these data, when combined with the differences revealed by biochemical, physiological and phylogenetic analyses, are sufficient to suggest that strain NTU $-104^{\mathrm{T}}$ represents a novel species of the genus

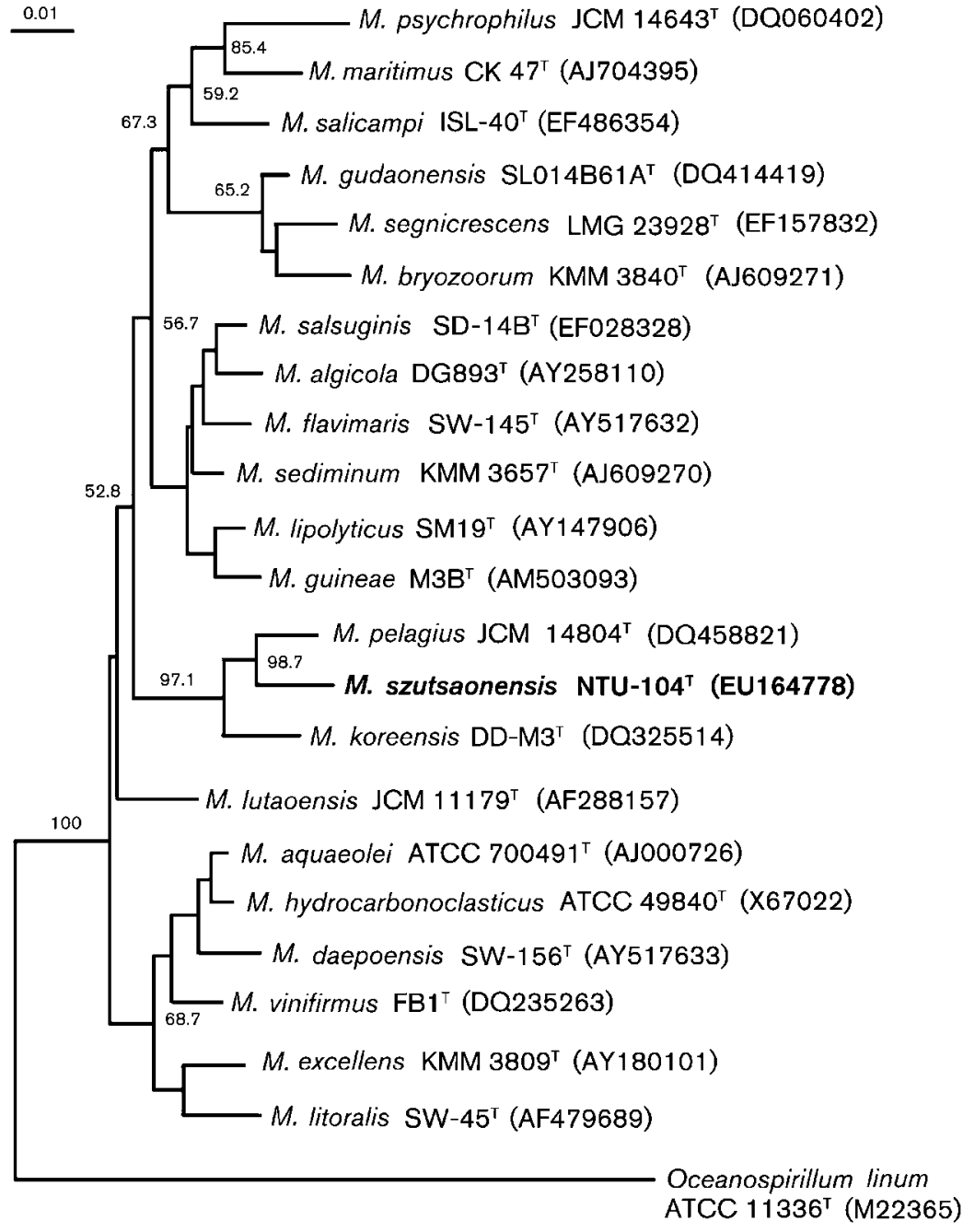

Fig. 1. Neighbour-joining tree showing the position of strain NTU-104 ${ }^{\top}$ with other species of the genus Marinobacter and related taxa based on 16S rRNA gene sequences. The bootstrap values from 1000 resamplings are indicated at nodes. Bar, 0.01 substitutions per site. 
Marinobacter, for which the name Marinobacter szutsaonensis sp. nov. is proposed.

\section{Description of Marinobacter szutsaonensis sp. nov.}

Marinobacter szutsaonensis (szu.tsao.nen'sis. N.L. masc. adj. szutsaonensis of szutsao, a former salt field located in southern Taiwan).

Cells are Gram-negative, rod-shaped $(0.3-0.6 \times 1.3$ $2.2 \mu \mathrm{m})$ and motile with a single flagellum. Colonies are irregular to regular, flat and light translucent and milky cream colour after $48 \mathrm{~h}$ at $37^{\circ} \mathrm{C}$. Growth occurs at $\mathrm{NaCl}$ concentrations of $0-20 \%(\mathrm{w} / \mathrm{v})$, with optimum growth at $5 \% \mathrm{NaCl}$. The optimum growth temperature is $35-40{ }^{\circ} \mathrm{C}$; growth is observed at $10-50{ }^{\circ} \mathrm{C}$. The $\mathrm{pH}$ range for growth is 6-8.5, with an optimum at $\mathrm{pH} 7.5-8.0$. Growth occurs under aerobic conditions. Nitrate reduction is positive, $\mathrm{H}_{2} \mathrm{~S}$ production is negative. Aesculin, acetate, casein, pyruvate, urea and gelatin are hydrolysed, but starch, Ltyrosine, Tween 20, Tween 80, DNA and xanthine are not hydrolysed. Oxidase- and catalase-positive. Acid is produced from D-glucose, D-mannose, maltose, D-mannitol, sucrose and D-galactose. Acid is not produced from cellobiose, D-fructose, melibiose, D-ribose, L-arabinose, melezitose, D-sorbitol, raffinose, trehalose or D-xylose. The following substrates are used as sole carbon sources: L-alanine, fumarate, D-glucose, malate, succinate, D-mannose, maltose and sucrose. Melezitose, trehalose, D-salicin, D-sorbitol, D-xylose, benzoate, sorbose, lactose, D-fructose, L-tryptophan, formate, L-rhamnose, L-glutamate, glycerol, gluconate, glutamate, succinate and citrate are not used. When assayed with the API ZYM system, alkaline phosphatase, esterase (C4), leucine arylamidase, valine arylamidase, trypsin, $N$-acetyl- $\beta$-glucosaminidase and $\alpha$ mannosidase are present, but esterase (C4), esterase lipase (C8), lipase (C14), $\alpha$-chymotrypsin, naphthol-AS-B1phosphohydrolase, $\beta$-galactosidase, $\alpha$-glucosidase, cystine arylamidase and $\alpha$-fucosidase are absent. The type strain is susceptible to ampicillin, bacitracin, carbenicillin, cefotaxime, chloramphenicol, erythromycin, kanamycin, nalidixic acid, nitrofurantoin, nystatin, penicillin, polymyxin B and tetracycline, but is resistant to neomycin, novobiocin, rifampicin and streptomycin. The predominant isoprenoid quinone is Q-9. Phosphatidylglycerol, diphosphatidylglycerol and phosphatidylethanolamine are the predominant polar lipids. The major fatty acids are $\mathrm{C}_{16: 0}, \mathrm{C}_{18: 1} \omega 9 c$, $\mathrm{C}_{16: 1} \omega 9 c, \mathrm{C}_{12: 0} 3-\mathrm{OH}$ and $\mathrm{C}_{12: 0}$.

The type strain, NTU $-104^{\mathrm{T}}\left(=\mathrm{BCRC} 17809^{\mathrm{T}}=\mathrm{CGMCC}\right.$ $1.7011^{\mathrm{T}}=\mathrm{JCM} 15751^{\mathrm{T}}$ ), was isolated from Szutsao, a discarded salt field located in southern Taiwan. The DNA $\mathrm{G}+\mathrm{C}$ content of the type strain is $56.5 \mathrm{~mol} \%$.

\section{Acknowledgements}

This work was supported by Grants from Council of Agriculture and National Science Council, ROC.

\section{References}

Antón, J., Oren, A., Benlloch, S., Rodríguez-Valera, F., Amann, R. \& Rosselló-Mora, R. (2002). Salinibacter ruber gen. nov., sp. nov., a novel, extremely halophilic member of the Bacteria from saltern crystallizer ponds. Int J Syst Evol Microbiol 52, 485-491.

Antunes, A., França, L., Rainey, F. A., Huber, R., Nobre, M. F., Edwards, K. J. \& da Costa, M. S. (2007). Marinobacter salsuginis sp. nov., isolated from the brine-seawater interface of the Shaban Deep, Red Sea. Int J Syst Evol Microbiol 57, 1035-1040.

Azeredo, J. \& Oliveira, R. (1996). A new method for precipitating bacterial exopolysaccharides. Biotechnol Tech 10, 341-344.

Descheemaeker, P. \& Swings, J. (1995). The application of fatty acid methyl ester analysis (FAME) for the identification of heterotrophic bacteria present in decaying Lede-stone of the St. Bavo Cathedral in Ghent. Sci Total Environ 167, 241-247.

Ezaki, T., Hashimoto, Y. \& Yabuuchi, E. (1989). Fluorometric deoxyribonucleic acid-deoxyribonucleic acid hybridization in microdilution wells as an alternative to membrane filter hybridization in which radioisotopes are used to determine genetic relatedness among bacterial strains. Int J Syst Bacteriol 39, 224-229.

Gauthier, M. J., Lafay, B., Christen, R., Fernandez, L., Acquaviva, M., Bonin, P. \& Bertrand, J. C. (1992). Marinobacter hydrocarbonoclasticus gen. nov., sp. nov., a new, extremely halotolerant, hydrocarbondegrading marine bacterium. Int J Syst Bacteriol 42, 568-576.

Gu, J., Cai, H., Yu, S.-L., Qu, R., Yin, B., Guo, Y.-F., Zhao, J.-Y. \& Wu, X.-L. (2007). Marinobacter gudaonensis sp. nov., isolated from an oilpolluted saline soil in a Chinese oilfield. Int J Syst Evol Microbiol 57, 250-254.

Guo, B., Gu, J., Ye, Y.-G., Tang, Y.-O., Kida, K. \& Wu, X.-L. (2007). Marinobacter segnicrescens sp. nov., a moderate halophile isolated from benthic sediment of the South China Sea. Int J Syst Evol Microbiol 57, 1970-1974.

Heyrman, J., Mergaert, J., Denys, R. \& Swings, J. (1999). The use of fatty acid methyl ester analysis (FAME) for the identification of heterotrophic bacteria present on three mural paintings showing severe damage by microorganisms. FEMS Microbiol Lett 181, 55-62.

Huo, Y. Y., Wang, C. S., Yang, J. Y., Wu, M. \& Xu, X. W. (2008). Marinobacter mobilis sp. nov. and Marinobacter zhejiangensis sp. nov., halophilic bacteria isolated from the East China Sea. Int J Syst Evol Microbiol 58, 2885-2889.

Kim, B.-Y., Weon, H.-Y., Yoo, S.-H., Kim, J.-S., Kwon, S.-W., Stackebrandt, E. \& Go, S.-J. (2006). Marinobacter koreensis sp. nov., isolated from sea sand in Korea. Int J Syst Evol Microbiol 56, 2653-2656.

Komagata, K. \& Suzuki, K. (1987). Lipid and cell-wall analysis in bacterial systematics. Methods Microbiol 19, 161-207.

Liebgott, P.-P., Casalot, L., Paillard, S., Lorquin, J. \& Labat, M. (2006). Marinobacter vinifirmus sp. nov., a moderately halophilic bacterium isolated from a wine-barrel-decalcification wastewater. Int J Syst Evol Microbiol 56, 2511-2516.

Mas-Castellà, J. \& Guerrero, R. (1995). Poly- $\beta$-hydroxyalkanoate determination in bacteria from aquatic samples. J Microbiol Methods 22, 151-164.

Mata, J. A., Martinez-Cánovas, J., Quesada, E. \& Béjar, V. (2002). A detailed phenotypic characterisation of the type strains of Halomonas species. Syst Appl Microbiol 25, 360-375.

Mesbah, M., Premachandran, U. \& Whitman, W. B. (1989). Precise measurement of the $\mathrm{G}+\mathrm{C}$ content of deoxyribonucleic acid by high-performance liquid chromatography. Int J Syst Bacteriol 39, 159-167. 
Montes, M. J., Bozal, N. \& Mercadé, E. (2008). Marinobacter guineae sp. nov., a novel moderately halophilic bacterium from an Antarctic environment. Int J Syst Evol Microbiol 58, 1346-1349.

Shin, Y. K., Lee, J.-S., Chun, C. O., Kim, H.-J. \& Park, Y.-H. (1996). Isoprenoid quinone profiles of the Leclercia adecarboxylata KCTC $1036^{\mathrm{T}}$. J Microbiol Biotechnol 6, 68-69.

Stackebrandt, E. \& Liesack, W. (1993). Nucleic acids and classification. In Handbook of New Bacterial Systematics, pp. 152-189. Edited by M. Goodfellow \& A. G. O'Donnell. London: Academic Press.

Thompson, J. D., Higgins, D. G. \& Gibson, T. J. (1994). CLUSTAL W: improving the sensitivity of progressive multiple sequence alignment through sequence weighting, position-specific gap penalties and weight matrix choice. Nucleic Acids Res 22, 4673-4680.
Wang, C. Y., Chang, C. C., Ng, C. C., Chen, T. W. \& Shyu, Y. T. (2008). Virgibacillus chiguensis sp. nov., a novel halophilic bacterium, isolated from Chigu, a previously commercial saltern located in southern Taiwan. Int J Syst Evol Microbiol 58, 341-345.

Xu, X. W., Wu, Y. H., Wang, C. S., Yang, J. Y., Oren, A. \& Wu, M. (2008). Marinobacter pelagius sp. nov., a moderately halophilic bacterium. Int J Syst Evol Microbiol 58, 637-640.

Yoon, J.-H., Lee, M.-H., Kang, S.-H. \& Oh, T.-K. (2007). Marinobacter salicampi sp. now. isolated from a marine solar saltern in Korea. Int $J$ Syst Evol Microbiol 57, 2102-2105.

Zhang, D. C., Li, H. R., Xin, Y. H., Chi, Z. M., Zhou, P. J. \& Yu, Y. (2008). Marinobacter psychrophilus sp. nov., a psychrophilic bacterium isolated from the Arctic. Int J Syst Evol Microbiol 58, 1463-1466. 